\title{
史跡岡城跡におけるシークェンス景観の分析
}

\section{An Analysis of Sequential Landscape in the Historic Site of Oka Castle}

\author{
加藤 祐介* 吉田 博宣** \\ Yusuke KATO Hironobu YOSHIDA
}

\begin{abstract}
Recently the environmental, landscape and utility planning for restorative historic sites becomes an important issue from an aspect of contribution toward the regional development. This paper presents a basic study on an analysis of the sequential landscape for the restorative landscape planning in a historic site, the ruins of Oka castle. Five circulation routes in the castle site were selected as visitors' main routes, and the sequential photographs on each route were prepared. The semantic differential (SD) test and watching point test were carried out to the students by showing those photographs. As a result, all pictures of the sequential landscape were classified into "one point of attention" type, "wide range of attention" type and "whole range of eyesight" type. The relation between each type and the evaluative result of SD test was clarified. The characteristics of five routes were pointed out, while the landscape components along the routes were related to those types.
\end{abstract}

Keywords: sequential landscape, landscape components, semantic differential test, watching point test, historic site キーワード：シークエンス景観, 景観構成要素, $S D$ 法評定実験, 注視部分指摘試験, 史跡

\section{1.はじめに}

近年, 文化財としての史跡の保存と活用を目的とした公園化に よる環境整備の実施が増加傾向にある。なかでも地域計画におい て高いポテンシャルを有しているのが近世城郭跡である。それは 地域の象徵的な性格をむち, 地域住民の文化的要求を結びつけて いくほか, 観光資源として地域活性など, 様々な活用に即した環 境整備が行われている。本研究の対象地である岡城跡は, 大分県 竹田市に立地する近世城郭跡である。岡城跡は, 明治維新後に城 館が取り壊され，昭和 11 年に国史跡に指定された。滝廉太郎の 「荒城の月」のモデルであある。2つの河川に挟まれた急峻な細 尾根上に展開しており, 広大な城内には天然の地形を活かした数 多くの遺構が残っている。本城跡は, 1984 年度に策定された 「史跡岡城跡保存整備計画」に基づいて遺構の発掘調査が実施さ

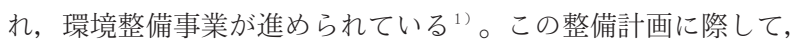
変化的な様相をむつシークエンス景観は岡城跡の特徵のひとつ之 いえ, この特徵を把捉し, 整備計画の指標として示すことが必要 であると考えた。既往のシークエンス景観の評価に関する研究は, 都市地域を対象としたものを中心として数多くおこなわれている。 歩行空間の研究では, 船越らの街路空間 ${ }^{2)}$ や参道空間 ${ }^{3)}$ がある。 材野ら ${ }^{4)}$ は回遊式庭園を対象としておこなっている。農村景観の シークエンス評価については竹内ら ${ }^{5)}$ や内海ら ${ }^{6)}$ の研究がある。 本研究では, これらの研究に加えて, 史跡という限定的な領域性 をむつ空間を対象とし, かつ文化財としての史跡の整備計画に資 するひとつの手法としてのシークエンス景観に関する評価研究と して位置づけたいと考える。本研究は, 対象地の主要動線におけ るシークエンス景観の特徴を示し, その評価の要因を明らかにす ることを目的とする。

\section{2. 調査方法}

(1) トレース調査による調査対象画像の抽出

2001 年 10 月 28 日，現地に扔いて利用実態を把捉する目的で,
無作為抽出の来訪者 20 グループ計 145 人を対象としたトレース 調查を実施した。調査内容は, 滞留時間, 行動コース, 展望等の 立ち止まり地点，言動等の項目についてグループごとに追跡，記 録した。この結果，対象地の規模に対して滞留時間が非常に短い 点, 行動コースがほぼ 1 動線に集中している点が挙げられ, 活用 が対象地全体の 1 部分に限られていることが明らかになった。こ の理由としては，来訪者を誘導するための明確な順路設定，ある いは整備が不十分である点が指摘できる。また, 眺望あるいは動 線上の景観が，来訪者を誘導するうえで重要な要素であることが 予測された。この調查結果にもとづいて, 主要動線 5 ルートを抽

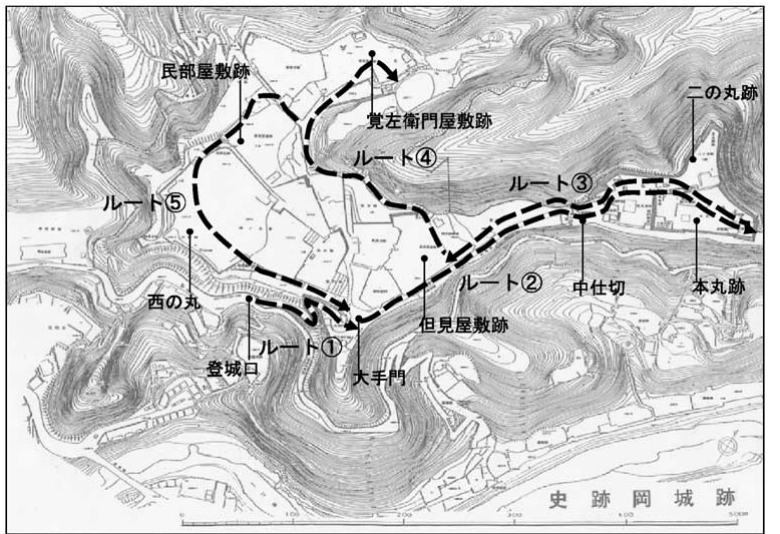

図ー 1 史跡岡城跡および調査対象ルート

表 -1 調査対象ルートおよびポイント数

\begin{tabular}{|c|c|c|}
\hline & 行程 & ポイント数 \\
\hline ルート(1) & 登城口ー大手門 & 18 points \\
\hline ルート(2) & 大手門 $\rightarrow$ 中仕切 $\rightarrow$ 本丸跡 & 18 points \\
\hline ルート(3) & 本丸跡 $\rightarrow$ 中仕切 $\rightarrow$ 但見屋敷跡 & 14 points \\
\hline ルート(4) & 但見屋敷跡 $\rightarrow$ 清水谷 $\rightarrow$ 覚左衛門屋敷跡 & 15 points \\
\hline ルート(5) & 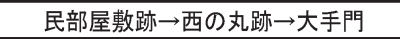 & 18 points \\
\hline
\end{tabular}

*滋賀県立大学大学院環境科学研究科 ${ }^{*}$ 日本大学生物資源科学部 
出した（図－1）。これらの動線においてルート(1) 5 m 間隔, その他の 4 ルートは $15 \mathrm{~m}$ 間隔の地点を, 調査対象ポイントとし た。ルート (1)を $5 \mathrm{~m}$ 間隔とした理由は, 屈折点が多く, $15 \mathrm{~m}$ 間隔 にした場合, 調査において動線の連続性が認識されにくいと判断 したためである。また, 動線上の屈折点等により景観の構造が大 きく変化するポイントについても適宜追加した。調査対象ルート 抢よびポイント数は, 表一 1 に示したと抢りである。撮影条件と して, 視高は $150 \mathrm{~cm} て ゙ 一$ 定とし, 視角は水平方向とした。また, 撮影設定として, 焦点を無限大に固定したデジタルカメラ（焦点 距離 $38 \mathrm{~mm}$ に相当）を用い, 画像サイズは縦 $640 \times$ 横 480pixel と した。以上の条件で, 2002 年 10 月 11 日に, 現地において調査 対象ポイントごとに撮影を㧍こなった。

\section{（2）注視部分指摘試験および SD 法評定実験}

これらの景観画像を刺激媒体として, 注視部分指摘試験および $\mathrm{SD}$ 法評定実験を抢こなった。被験者は, 日本大学造園学・緑地 学研究室に所属する学生 21 人とした。画像の提示方法はスクリー ンを用い, 映写画面の大きさは $244 \times 183 \mathrm{~cm}$ と, 被験者の位置 を投影面より約 3.85〜 7.45 m の範囲に配置した。このときの被験 者のスクリーンに対する視野角は被験者の平均的な位置で, 水平 方向が $28^{\circ}$, 垂直方向が $21^{\circ}$ であった。この条件のもとで, 被 験者に各画像の注視範囲の記録を求めた。注視範囲の記録方法は, 5 ルート計 83 ポイントの調查対象画像を, 回答用として縮小し たもの $(\mathrm{W} 64.9 \mathrm{~mm} \times \mathrm{H} 48.7 \mathrm{~mm})$ を一人ずつに配布し，そこに最初 に注視した部分の範囲を直接記入させた。1枚あたりの提示時間 は約 5 秒とし, 進路に従って連続的に提示した。この際, 提示順 序によって評価に影響があらわれると判断したため, トレース調 查の結果にもとづいて, 来訪者の実際の軌跡に最む近いと考えら れる順序 (ルート (1)ポイント (1) ールート (5)ポイント (18) で提示し た。その回答範囲について各画像を 391 個（横 $23 \times$ 縦 17 個）の 正方グリッドに分割して集計し, 各グリッドにおける注視率を算 出し, グラフ化した。注視部分指摘試験において, 1 つのルート の画像をすべて提示し終わった直後に, SD 法による評定実験を おこなった。被験者に対して 23 対の形容詞について 5 段階の評 定をむとめた。実験にもちいた形容詞対は, 現地調査および既往 の自然景観の研究 7) を参考に収集し, 本研究に適当であると考え られるむのを選出した。

\section{（3）景観構成要素の占有割合}

対象地を構成する景観要素の動線上での変化を調査する目的で, ポイント毎の画像に打ける景観構成要素を調査した。調査対象の 構成要素の項目は, (1)園路, (2)空地・遺構, (3)人工物, (4)樹林・ 山並み, (5)石垣, (6)崖, (7)空の 7 要素である。「空地」,「遺構」 を同一の要素とした理由は, 遺構は現在覆土されている場合が多 く, 画像による判断はつかないと考えられるためである。「人工 物」とは, 史跡の来訪者に対して便宜的に設置したあのか, 史跡 とは直接関係性の乏しい建造物である。具体的には, 石碑, 手す り, 看板類, 神社建築, 臨時施設をさす。また, 「樹林・山並み」 要素については, 樋口忠彦の近景 $(360 \mathrm{~m}$ 以内）・中景（360 $\mathrm{m} \sim$ $4.4 \mathrm{~km})$ ・遠景（3.3km〜 4.4km以上）の分類方法を参照した ${ }^{8)} 。 こ$ の分類にもとづいて対象地の景観と照合し, 近景は, 史跡指定範 囲内の景観（対象地内の他の場所を見たときの景観），中景は， 竹田市街と岡城跡を取り囲む山々の景観（岡城跡を取り囲む丘や 山々で視線が最初に遮断されるところまで), 遠景は, 九重山系 と久住高原, 阿蘇山および祖母・傾山系とした。これらの各要素 の画像に占める面積割合を算出した。なお, 面積の算出には, Vector Works を使用した。

\section{3. 調査結果}

(1) 注視部分指摘試験

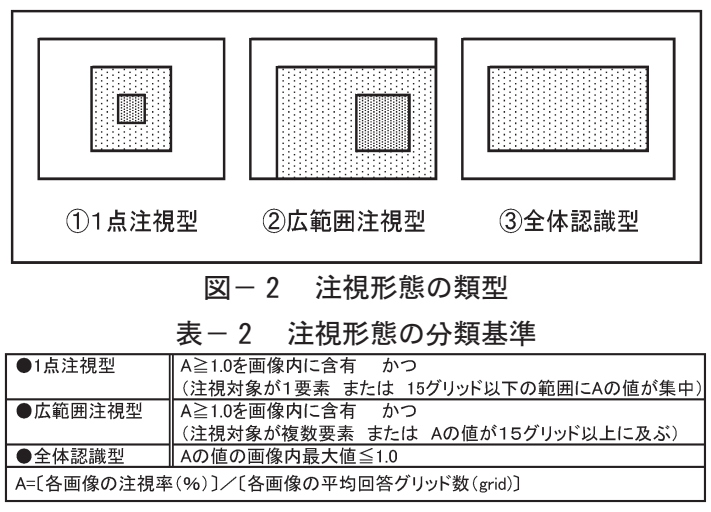

注視部分指摘試験において, 各画像の注視率グラフと平均回答 グリッド数から, 注視形態は以下のパターンに分類された（図一 2 )。類型の分類方法および基準は, 表一 2 のとおりである。

(i ) 1 点注視型

1 点に焦点が集中する注視形態である。1 点注視型は特徽的な 要素が視界に入るとき, あるいは景観構成に奥行性があるときに とる形態である。具体的には, 登城口から大手門に至る動線にお いて, 大手門の石垣がはじめて視界に入るとき (ルート(1)), 覚 左衛門屋敷跡から三の丸, 二の丸跡の石垣を眺望するとき（ルー 卜 (4)，中・遠景の山並みが眺望できる場合（ルート(5)他）に, この注視形態となる(図一 3 )。

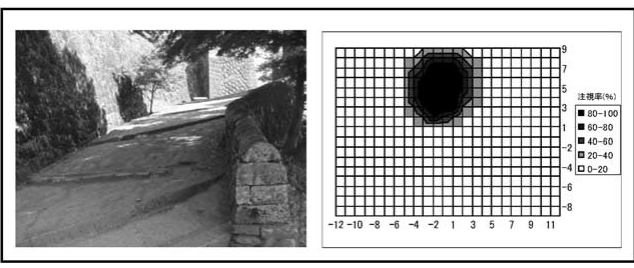

図ー 3 1点注視型（ルート(1)ポイント(12)

（ii）広範囲注視型

広範囲を注視し，広範囲の焦点をむつ注視形態である。閉鎖的 空間から開放的空間に移行する際，またその空間内においてこの 形態をとる。広範囲注視型は大手門のエントランス的空間（ルー ト (2)）や西の丸跡（ルート(5)）に打いてこの形態となる (図一-4)。

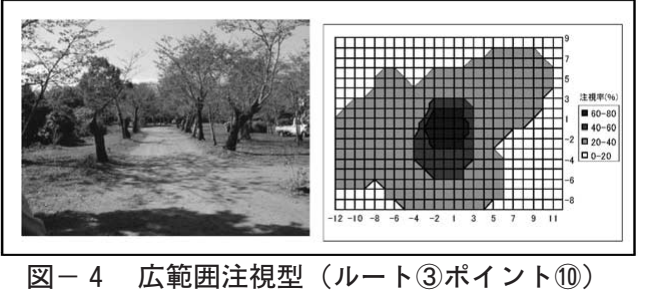

(iii）全体認識型

焦点をむたない注視形態である。景観中に 1 つの要素が大きく 占有した場合にこの形態をとる。ルート(1)に扔いてこの注視形態 をとることが多いが，これは急な登坂のため，構成要素として園 路の占有が大きくなったためであると考えられる（図－5）。

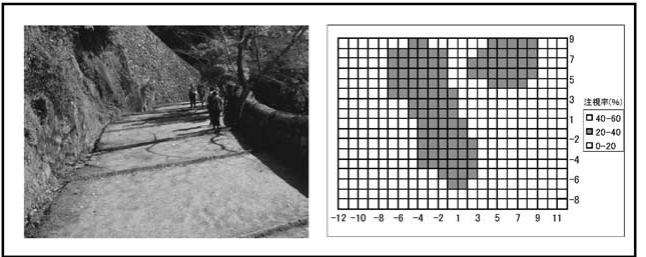

図ー5 全体認識型（ルート(1)ポイント(5)） 


\section{（2）景観構成要素の占有割合}

（i ）ルート(1)（図-6）：順路は, 急な登坂または階段で構成 される。このため, 全体を通して園路要素の占有割合が大きい。 また，継続的に石垣が大きな割合で占有する。構成要素数は他ルー 卜と比較して少数であり, 至近景のみで構成される要素である。

(ii) ルート (2) (図-7): 大手門跡から籾倉跡（ポイント (1) (7)）においては大きな変化はみられず，近景樹林が大きな割合を 占有する。また，中仕切（ポイント (9)～(12)）に押いて石垣が大き な割合を占有する。それ以降の三の丸跡から本丸跡にいたる順路 では, 各遺構が立体的に連続するため構成要素の増減が多い。ま た, 中仕切以降においては中・遠景を含む構成要素数の多い, 多 様なルートとなる。また，人工物要素の連続的な占有がみられる。 （iii）ルート(3)（図-8)：ルート(2)の復路であり, 中仕切に抒 いて石垣の占有する割合が大きい（ポイント (6)～(8))。近景樹林 がルート全体をと打して連続的に占有する。また，少ない割合で あるが, 近景人工物の占有が連続的である点が特徵といえる。近 景の要素のみで構成されるルートである。

(iv) ルート (4) (図-9)：ルート全体をと扎して石垣と樹林が 大きな割合を連続的に占有する。また覚左衛門屋敷跡において空 地の割合が大きくなる（ポイント(12) (15)。

（v）ルート (5)（図-10）：ルート全体をと扎して, 遺構が連続 し明確な園路整備がないため, 空地の占有が大きい。

特に民部屋敷跡（ポイント (4)〜 (6)), 西の丸跡（ポイント (8)〜(11) に扔いて顕著である。また西の丸跡に扔いて中・遠景の占有が大 きくなるのが特徴である。西の丸跡から大手門にかけては比較的 变化が少ない。構成要素数が多いのも特徴といえる。

\section{（3）SD 法評定実験}

$\mathrm{SD}$ 評定実験に打ける被験者の評定結果を 1 点〜 5 点に数值化 し, 因子分析にかけた。最大相関係数による反復推定ののち, バ リマックス法による直行回転を抢こない，表一３の結果を得た。 この結果, 因子 I 「開放性」, 因子 II「総合評価性」, 因子III「力 量性」, と意味づけを抢こなった。3 因子による回転後の各因子 の寄与率は, 表一 3 に示すと㧍りである。これらの因子をむちい て，因子得点を算出した。寄与率の高い順に，因子 I $\times$ 因子 II, 因子 I $\times$ 因子III を分析対象とした。まず，因子「開放性」をX軸， 「総合評価性」をY軸とした因子得点散布図（図一11)，「開放性」 をX軸, 「力量性」を $\mathrm{Y}$ 軸とした因子得点散布図（図－12）にお いて, 各ルートの判定は以下のようになった。ルート(1)は「開放 性」「総合評価性」ともに低い判定であったが,「力量性」では 高い判定であった。つまり，ルート(1)に対する判定は, 閉鎖的で あり, あまり好ましくないが，力強さを感じるルートであるとい える。ルート(2)では,「開放性」に扔いてやや高い判定,「総合評 価性」では低い判定であった。「力量性」では, やや低い判定で あった。ルート(3)では,「開放性」がやや低い判定，「総合評価性」 が高い判定であった。「力量性」では，やや低い判定であった。 ルート(4)では, 「開放性」が高い判定,「総合評価性」がやや低い 判定であった。「力量性」では，やや高い判定であった。ルート (5)は,「開放性」がやや高い判定であり，「総合評価性」が高い判 定であり，「力量性」ではやや低い判定であった。

\section{4. 考察}

\section{（1）各ルートにおけるシークェンス景観の構造特性}

各ルートの注視形態, 注視対象要素抢よび景観構成要素の占有 割合を比較し, これらの関係から対象地におけるシークエンス景 観の構造特性を考察する（表一 4 ）。

$$
\text { (i) ルート (1) }
$$

ルート(1)は, 登城口から第 1 屈折点にいたる部分（ポイント(1)（8）に扔いて全体認識型をとる場合が多い。順路の構造上, 全体
を通して登坂や階段の園路要素が高い割合を占有するが，この要 素を注視する際には全体認識型をとった。反対に低い割合の要素 を注視する際には 1 点注視型をとり, その対象要素の接近に伴い 占有割合が増加するにしたがって広範囲注視型への移行がみられ た。全体をとおして画像中の占有割合の小さい要素を注視する傾 向にあるが，これが逆転するのは，その要素の占有割合に顕著な 増加がみられる場合であった。具体的にいうと，ルート(1)全体を

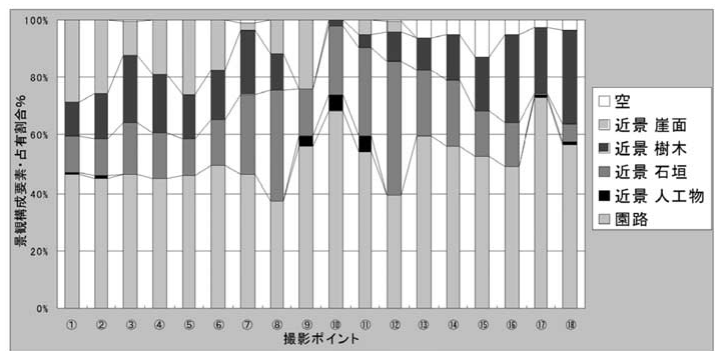

図一 6 ルート (1) 景観構成要素の占有割合

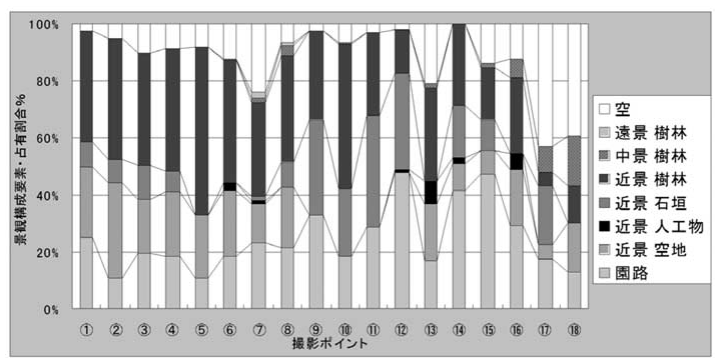

図ー7 ルート(2) 景観構成要素の占有割合

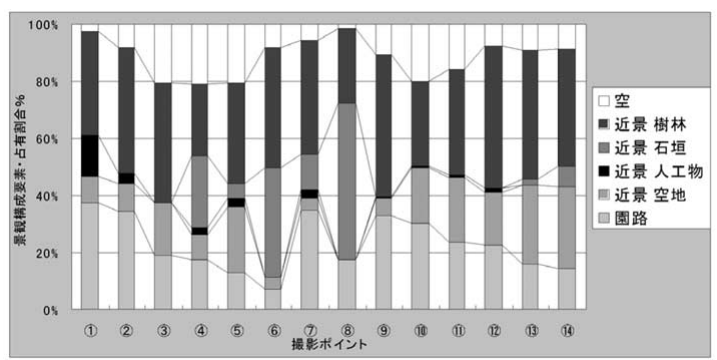

図-8 ルート(3) 景観構成要素の占有割合

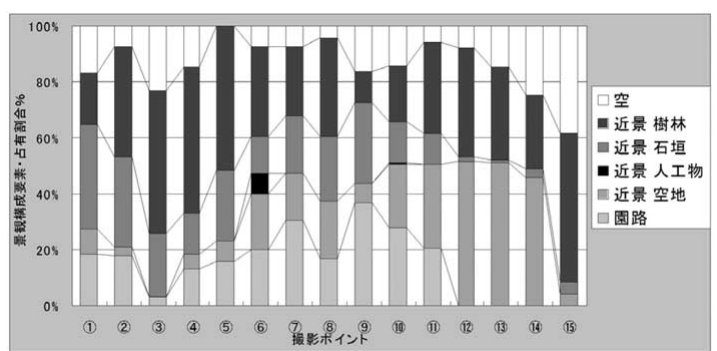

図－9 ルート(4) 景観構成要素の占有割合

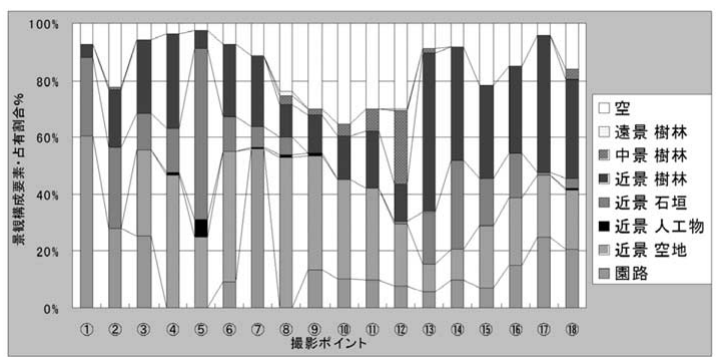

図ー10 ルート(5) 景観構成要素の占有割合 
通して占有割合の大きい要素は園路, 石垣であり, 小さい要素と は, 人工物あるいは樹林がこれに該当する。また, 数ポイントに わたって連続的に同一の要素を注視する傾向がみられた。ポイン ト (11)－(12)部分において動線上の屈折点によって景観中に石垣の割 合が急増すると, 注視形態に变化はないが, 注視対象は石垣に移 行した。また, ルート(1)は他のルートと比較して構成要素の占有 割合の变化が少なく, 要素数についてあ少数であった。これは, 他に扔いて中景抢よび遠景の樹林・山並みが要素としてあらわれ るのに対し, ルート(1)では, 要素は近景で構成されるため, 要素 数が少ない結果となったためである。

(ii) ルート (2)

ポイント (1)の大手門跡のエントランス空間において, 注視形態

表 -3 因子分析結果

\begin{tabular}{|c|c|c|c|}
\hline 形容詞対 & $\begin{array}{c}\text { 因子 I } \\
\text { 「開放性」 } \\
\end{array}$ & $\begin{array}{c}\text { 因子 II } \\
\text { 「総合評価性」 }\end{array}$ & $\begin{array}{c}\text { 因子III } \\
\text { 「力量性」 } \\
\end{array}$ \\
\hline 陰気な一陽気な & 0.795 & -0.238 & 0.050 \\
\hline 開放的な一閉鎖的な & -0.730 & 0.297 & 0.140 \\
\hline 広い一狭い & -0.728 & 0.112 & 0.085 \\
\hline 寂しい一活気のある & 0.725 & -0.162 & 0.182 \\
\hline 暗い一明るい & 0.716 & -0.218 & 0.100 \\
\hline 人工的な一自然な & 0.695 & -0.272 & -0.171 \\
\hline 単調な一変化に富んだ & 0.660 & -0.127 & 0.432 \\
\hline 雄大な一矮小な & -0.610 & 0.130 & -0.157 \\
\hline 緊張した一のんびりした & 0.568 & -0.472 & -0.252 \\
\hline 動的な一静的な & -0.526 & -0.282 & -0.177 \\
\hline 連続的な一不連続な & 0.463 & 0.364 & 0.152 \\
\hline よいーわるい & -0.355 & 0.682 & -0.041 \\
\hline 醜い一美しい & 0.421 & -0.661 & 0.123 \\
\hline 不調和の一調和のとれた & 0.019 & -0.661 & 0.146 \\
\hline 不快な一快い & 0.402 & -0.614 & 0.138 \\
\hline 嫌な一好きな & 0.472 & -0.601 & 0.131 \\
\hline 親しみやすいーよそよそしい & -0.445 & 0.585 & 0.117 \\
\hline 魅力的な一つまらない & -0.357 & 0.579 & -0.420 \\
\hline 不安定な一安定した & -0.227 & -0.546 & 0.146 \\
\hline 弱々しいーカ強い & -0.039 & -0.175 & 0.815 \\
\hline 繊細な一大胆な & 0.024 & 0.232 & 0.617 \\
\hline 平面的な一立体的な & 0.262 & -0.264 & 0.563 \\
\hline 見慣れたーめずらしい & -0.017 & -0.144 & 0.391 \\
\hline 寄与率 & $25.98 \%$ & $17.39 \%$ & $9.70 \%$ \\
\hline 累積寄与率 & $25.98 \%$ & $43.37 \%$ & $53.07 \%$ \\
\hline
\end{tabular}

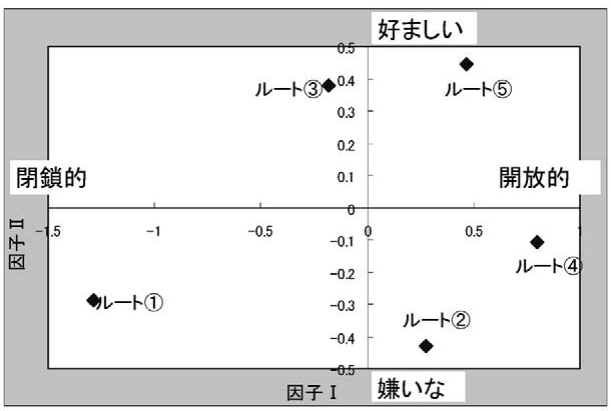

図-11 因子 $1 \times$ 因子 2 因子得点散布図

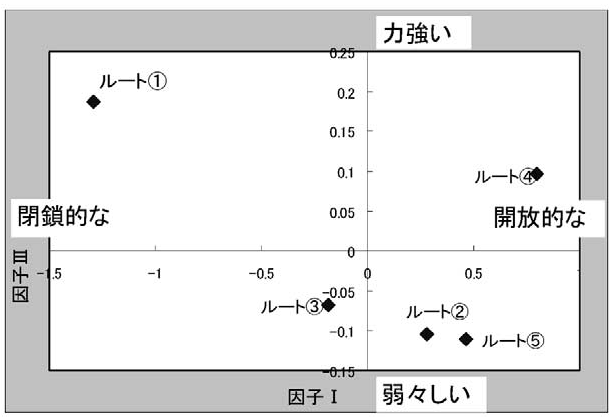

図-12 因子 $1 \times$ 因子 3 因子得点散布図
は広範囲注視型をとっている。ポイント (2)-(5)では，1点注視型 または広範囲注視型をとっており, 視線は進路方向にほぼ一定で ある。進路に対して左側が石垣, 右側が樹林によって構成され視 界が狭まっている空間構成となっている。ポイント (6)-(9)は籾倉 跡から中仕切にいたる順路である。注視形態は，中仕切石垣が接 近するにつれて全体認識型から広範囲注視型へと移行している。 また，ルート(2)では画像(6)以降特に，記念碑など後補の人工物が 増加し，これを注視する傾向もみられた。ポイント 8), (13)におい て中景の樹林・山並み要素は, 微小な増加であっても注視対象之 なった。このときの注視形態は広範囲注視型をとった。ポイント (17)，(18)に打ける中景・遠景山並みを注視対象之するときは，広範 囲注視型から 1 点注視型への移行がみられた。その他のポイント では注視形態としては多様であるが，園路を注視対象とすること が多い。注視形態が一定でない理由として, ポイント (1)-(5)では, 注視形態の移行時に微小であるが園路要素の増減が認められた。

(iii) ルート (3)

ルート (2) と同様に，中仕切石垣の部分（ポイント (6)-(8)）では 石垣を注視対象によっているが，注視形態はルート(2)では全体認 識型であったのと異なり, 広範囲注視型をとっている。この違い は，この部分に至る過程の空間的な相違にあると考えられる。ま ず，ルート(2)では，中仕切石垣が徐々に視界に入っていき石垣の 占有割合むそれにしたがって増加したが，ルート(3)では，ポイン ト (5)一 (6)に至る変化は大きい。これは, 石垣の占有割合が顕著に 増加しているのをみても明らかである。樹木・山並み要素および 石垣要素は，前ポイントから急増する傾向にあるときはこれを注 視する傾向があるが，人工物要素を注視する際には構成要素の占 有割合の増減との関係は認められず，わずかの占有でもほとんど の場合これを注視する。ポイント (10)以降は, 景観構成要素の占有 割合の変化は少なく, 動線的特徵から注視対象要素は常に進路方 向の園路要素を含んでいる。

(iv) ルート (4)

ポイント (1)-(3)では，ルート(2)のポイント (2)-(5) と同様に視線 は進路方向にほぼ一定であるが，注視形態は，1点注視型をとっ ている。これは, 園路の線形が比較的直線であり，構成要素の占 有割合の变化が規則的となったため，方向性が強調されたことが 理由として挙げられる。また, 視対象要素の占有割合の増加に伴っ て1点注視型の注視形態がより強調されていくことが確認された。 また, 他ルートと同様に, 景観構成要素の占有割合之注視対象要 素の関係に扔いて，樹林・山並み要素は占有割合の増加によって, 注視対象要素となることが明らかとなった。また人工物について も微小な増加にかかわらず注視することが明らかとなった。

( v ) ルート (5)

ポイント (2)-(3)にかけて注視形態は，全体認識型から広範囲注 視型に移行している。この理由としてポイント (3)以降では空地・ 遺構要素の占有割合が大幅に増加している。ポイント (3)一(6)にお いて，ポイント(5)では，石垣の占有割合の増加によって，これを 注視対象とするが，それ以外のポイントでは構成要素の变化はあ まりなく, 注視対象要素むほぼ空地・遺構で一定である。ポイン ト (7)では，登坂であるため園路の占有割合が大きくなるが，これ を注視せずに進行方向の空地・近景樹林を注視した。ポイント 8(12)では，ほぼ広範囲注視型をとっている。ポイント (10)において1 点注視型をとっているが, 中・遠景の樹林・山並み要素の増加に よって明確に視覚できるようになり一時的にこの注視形態をとっ たものと考えられる。

ルート (5)では占有割合の小さい要素を注視する傾向はみられな かったが, 要素の如何にかかわらず増加傾向のある要素を注視し た。またこれに当てはまらないものは, 屈折点等により景観構成 要素の変化が小さいポイントであった（ポイント (3), (8), (13))。 


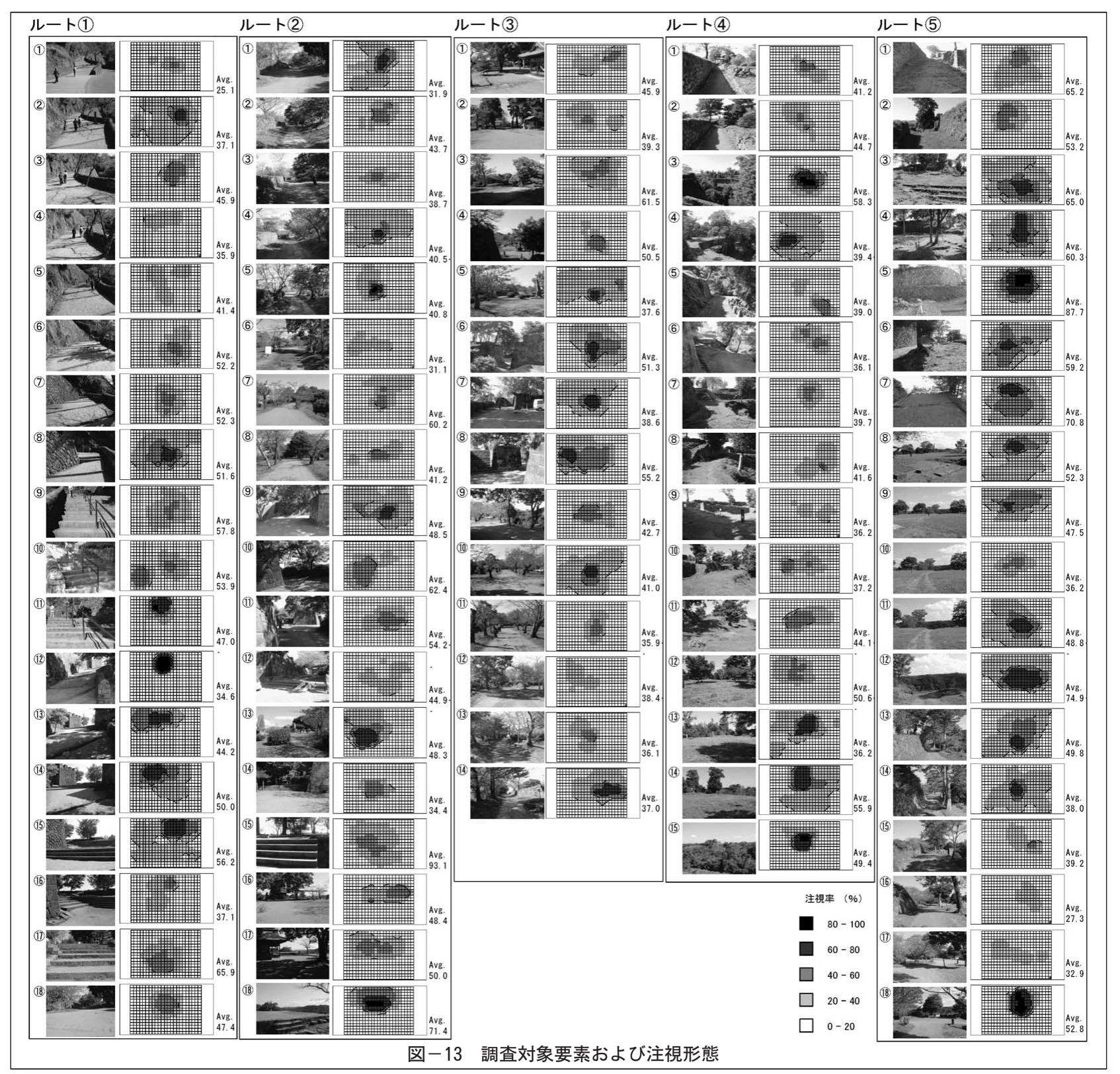

ルート（5)は，全体をとおして広範囲注視型をとる場合が多いが， 全体認識型への移行に構成要素の占有割合の变化との関係性はみ られなかった。

\section{（2）５ルートの比較によるシークェンス景観の構造的特性}

5 ルートの共通点あるいは相違点の比較・考察を打こなうこと によって, 対象地のシークエンス景観の構造特性が以下のように 明らかになった。

（i ）画像中に 1 つの要素が高い割合を占有した場合, その要素 を注視する際には全体認識型をとる。反対にその他の低い割合の 要素を注視する際には, 1 点注視型をとる場合が多い。また, 至 近景に構成要素が集中し, 突出した占有割合の要素を含まない場 合に，注視特性として広範囲注視型となった。このとき焦点とな るのは，画像中に扔いて低い占有割合の人工物または石垣であっ た。これは対象地の景観構成が不整形の自然的要素を多く占有す るため，整形的要素に視点が集中するもの之考えられる。

(ii）ルート (2)のポイント (7)-(9)とルート (3)のポイント (6)-(8)は 同じ中仕切の空間の往路と復路である。同程度の石垣要素の占有 をむつ。しかしながら, 注視形態に扔いてその移行に違いがみら
れる。ここで考えられるのは，同様の対象物を認識した場合で屯， それに至るシークエンス景観の構造的相違によって異なった捉え られ方をする場合があるということである。連続性のあるシーク エンス景観の変化と，断続的な変化ではこの場合でもあきらかな ように, 対象にいたる間での景観構成の顕著な变化は被験者の判 定に影響をもたらすと考えられる。ルート(2)では，接近につれて 広範囲注視型から全体認識型への移行がみられ，ルート(3)の場合 では, 広範囲注視型（ポイント(5)）のままで注視形態の移行はな

（iii）注視対象が景観構成上の特異要素である場合は，その占有 割合にかかわらず注視対象となると考えられる。岡城跡の場合に は，人工物がこれにあたる。

（3）シークェンス景観の構造とSD 法評定実験による判定・評 価の関係について

「開放性」の判定において高得点（開放的であるという判定を 得た）であった径路は，高得点順にルート (4)，(5)，(2)，(3)，(1)で ある。この中であ特に閉鎖的であるという判定であったのはルー ト (1)である。閉鎖的である景観構造的な要因のひとつとして, 景 
表 -4 注視形態および注視対象要素

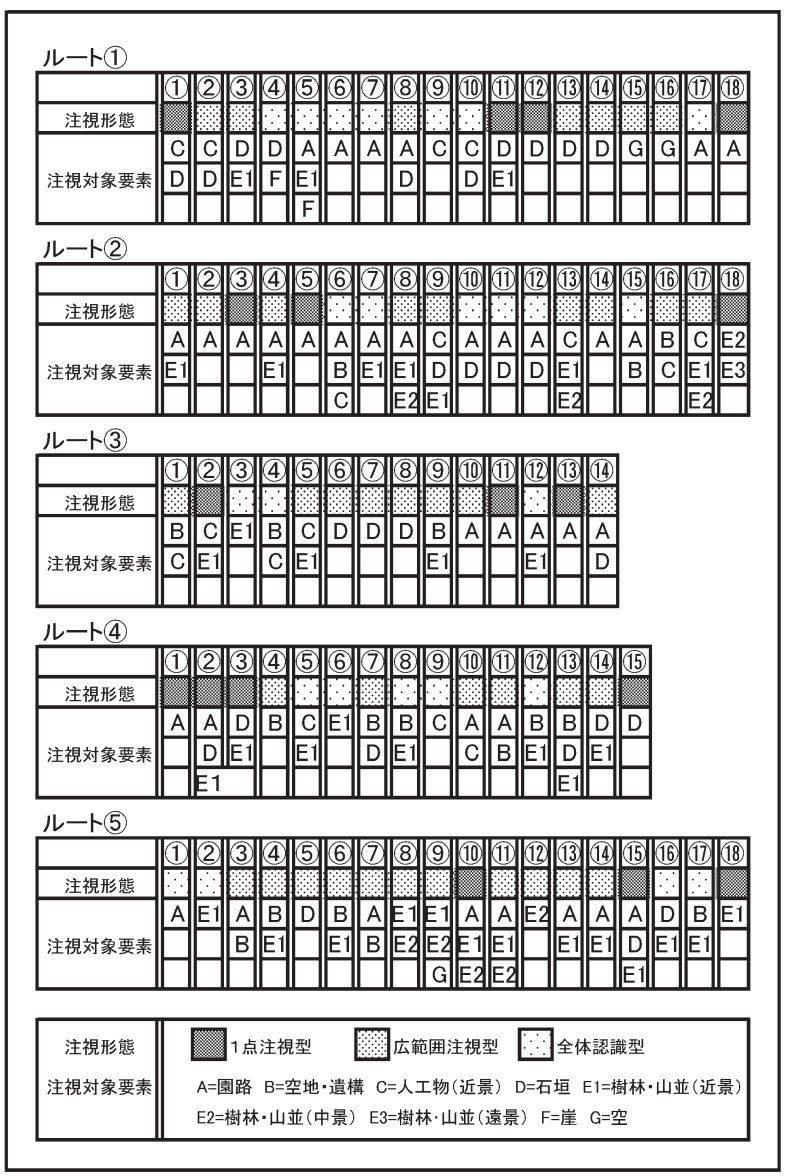

観構成要素の占有割合からも明らかなように, 園路要素がどのポ イントに扔いても平均的に $40 \%$ 以上を連続的に占有する特異な 構成となっていることである。また空要素の占有がほとんどなく， 石垣，崖等の垂直的空間要素が連続している点でも同様である。 開放性一閉鎖性の因子軸の判定として最も重要であると考えられ るのが, 石垣等の垂直要素々空地・遺構等の平面要素の空間構成 要素である。樹林等も垂直性があると考えられるが，樹林のよう な質的に透過性がある要素の連続的占有と, 崖, 石垣要素では, 空間の閉鎖性の判定は異なっていることは明らかである。また, ルート(1)に関しては, 順路が登坂のため, 園路要素が垂直要素で あると判定されていると考えられる。

「総合評価性」の評価に扔いて低得点であったのは, ルート (1) および(2)であるがこれらの構造的な共通点は, 同一の構成要素を 注視する傾向がみられ, また構成要素の変化が少ない点が挙げら れる。このときの注視形態として園路要素を注視する際には, 全 体認識型であった。また, これらの順路では, 微小な増加にかか わらず，人工物要素を連続して注視対象としていることが低得点 であった要因として考えられる。反対に「総合評価性」において 高得点であったルート(3)よび(5)では, 景観構成要素の占有割合 が比較的に多様でかつ变化的であり, 全体的に注視対象要素が一 定でない点, 注視対象要素として広範囲注視型をとることが多い といえる。

「力量性」の判定に打いて高得点であったのは, ルート(1) 抢よ び(4)である。これらに共通にみられる傾向は, 近景（城内景観） のみの要素で構成される動線であること, 連続して園路抢よび空 地・遺構要素が高い割合で占有すること, またこれを連続的に注 視する傾向があることが挙げられる。このときの注視形態として 同一の形態をとることはないが，ルート(1)では全体認識型から広
範囲注視型への移行がみられた。一方で, 低得点であったルート (2), (3), (5)の構造的特徵は, 景観構成要素の占有割合の変化から 明らかなように，空間構成の多様性を挙げることができる。同一 の要素がある程度均一にシークエンス景観を構成するようなルー ト (1)やルート (4)では，占有割合が増加傾向にある要素を連続的に 注視するような傾向は見られない。このことは各ルートのシーク エンス景観の「力量性」に起因していると考えられる。

\section{5.まとめ}

岡城跡のシークエンス景観の判定は,「開放性」「「総合評価性」 および「力量性」に起因していることが明らかになった。

「開放性」の判定で，特に「閉鎖的」之判定されるのは，(1)景 観構成が石垣や崖等の垂直性の高い要素が連続的に占有しており, (2)注視形態での特徵は, 全体認識型をとることが多く, (3)垂直的 要素を連続的に注視する場合であった。反対に「開放的」である と判定される場合, (1)景観構成は比較的多くの空地・遺構要素を 連続的に占有し，(2)れらの要素を多く占有するとき注視形態の 特徴として広範囲注視をとることが多い。「総合評価性」の判定 で，「好ましい」と評価される場合は，(1)構成要素の多様で，氻 つ变化的であり, (2)同一の要素を連続して注視しないこと, (3)注 視形態として広範囲注視型を連続的にとることが多い点が挙げら れる。また，反対に「嫌いな」評価を受ける場合は，人工物要素 の連続的に注視する場合が挙げられる。人工物要素は，特に構成 要素の占有割合の増減にかかわらず注視対象となりやすい。これ らの人工物の多くは，石碑あるいは案内のためのあのである。岡 城跡のシークエンス景観における景観の評価において, 被験者は, これらの人工物を歴史・文化的要素の石垣や遺構とそれをとりま く自然的要素とは異質であるとみなしているあのといえる。また, 「力量性」の判定が強くなるのは, (1)城内景観のみの要素で構成 される動線であること, (2)連続して園路および空地・遺構要素が 高い割合で占有すること，(3)またこれを連続的に注視する傾向が あること，の場合であった。

以上の上うに, 岡城跡の来訪者の順路に従ったシークェンス景 観の分析を, 景観構成要素, 注視形態, $\mathrm{SD}$ 法評定の面から扔こ ない，その特徴を一定程度明らかにすることができた。今後の当 史跡の整備に対しては, この調査結果をふまえて, さらに現地で の実際の来訪者に対する選好調查等を抢こなうことによって, よ り具体的な指針が得られるものと考えられる。

\section{補注及び引用文献}

1）竹田市教育委員会（1988）：史跡岡城跡保存整備基本計画

2 ) 船越徹・積田洋 (1987)：街路空間における空間意識之空間構成要素 との相関関係の分析（相関分析）一街路空間の研究（その 3 ）：日本 建築学会計画系論文報告集第 378 号, 49-57

3 ) 船越徹 (1988) : 参道空間の文節之空間構成要素の分析（文節点分析・ 物理量分析）参道空間の研究（その 1$)$ ：日本建築学会計画系論文報 告集第 384 号, 79-85

4) 材野博司・宮岸幸正（1992）：基本構造シークエンスと行動シークエ ンス景観の関係：日本建築学会計画系論文集第 502 号, 79-85

5 ) 竹内稔・藤本信義・三橋伸夫 (1995) : シークエンス景観と連続シー ン景観の評価構造分析：日本建築学会計画系論文集第 475 号, 119128

6 ) 内海志泉・古谷勝則・油井正昭 (2000) : 北海道美瑛町の農村地域に おけるシークエンス景観の分析：ランドスケープ研究 63(5), 783-788

7 ）児島隆政・古谷勝則・油井正昭（1995）：自然景観における好ましさ の評価構造に関する研究：ランドスケープ研究 58(5), 177-180

8 ）樋口忠彦（1975）：景観の構造：技報堂出版，22-23 